\title{
Towards understanding causality between work engagement and psychological capital
}

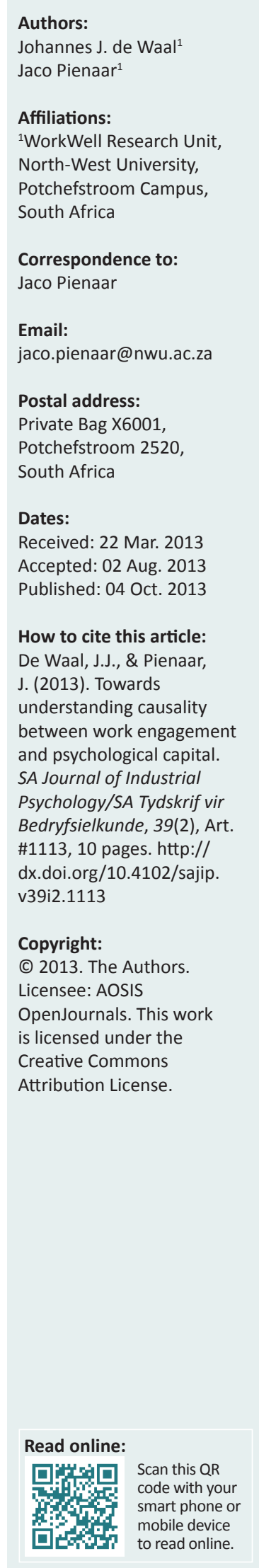

Orientation: It is of theoretical and practical interest to establish the sequential relationship between work engagement and positive organisational behaviour, as represented by the psychological capital (PsyCap) construct.

Research purpose: The main aim of this study was to conceptualise and investigate the causal relationship and temporal order in the relationship between PsyCap and engagement by means of longitudinal data.

Motivation for the study: The rationale for establishing the sequence of engagement and psychological capital lies in the fact that training interventions to enhance the organisational well-being of employees may need to be focused on either one or the other.

Research design, approach and method: A longitudinal study with a cross-lagged panel design was conducted; data was gathered by means of a survey that was constructed for the purpose of the study. The survey contained the Utrecht Work Engagement Scale (UWES), and a measure of PsyCap. All employees within a chemical factory $(N=1003)$ were approached to provide data; 163 employees participated.

Main findings: Results revealed that PsyCap at Time 1 (T1) did not significantly predict engagement at Time 2 (T2). Evidence does however exist that initial levels of employee engagement predict subsequent PsyCap.

Practical/managerial implications: Results suggest that employee interventions aimed at protecting and fostering employee engagement may have implications for subsequent employee psychological capital.

Contribution/value-add: As an empirical, longitudinal study to address the temporal order between PsyCap and work engagement, this study makes a contribution especially to theory, but also with practical implications by indicating that engagement precedes employee psychological capital.

\section{Introduction}

\section{Key focus of the study}

The South African and international business environments currently demand much more from employees than during any previous time in history (Rothmann, 2003). Modern organisations expect their employees to take a proactive approach, show initiative, develop a sense of responsibility and be committed to the execution of high performance standards (Bakker, Schaufeli, Leiter \& Taris, 2008). Organisations therefore require employees who feel energetic and are dedicated to and absorbed by their work, that is, who are engaged with their work (Bakker \& Schaufeli, 2008). To encourage engagement in organisations today, personal resources such as optimism, self-efficacy and resilience could be employed, as it is suggested that these personal resources facilitate work engagement (Bakker \& Demerouti, 2008). Such resources fall under the rubric of employee psychological capital (PsyCap) (Luthans, 2002a; Luthans, Luthans \& Luthans, 2004; Youssef \& Luthans, 2007). However, the temporal order between PsyCap and engagement has not been extensively researched, although some authors have theorised a likely reciprocal relationship (Bakker, Schaufeli, Demerouti \& Euwema, 2007; Sweetman \& Luthans, 2010). In other words, it is still unknown whether engagement leads to, is the consequence of or reciprocally interacts with employees' PsyCap. This study reports on an investigation into this sequential ordering of PsyCap and work engagement.

\section{Background to the study}

A key differentiator of competitive advantage and sustained organisational performance in the modern global economy is an organisation's employees or human capital (Luthans et al., 2004; Minervini, Meyer \& Rourke, 2003). The importance of employees' work engagement is 
highlighted by empirical evidence which proposes that engagement is positively linked to positive organisational outcomes, including job performance (Bakker \& Bal, 2010; Halbesleben \& Wheeler, 2008), client satisfaction (Salanova, Agut \& Peiro, 2005), financial returns (Xanthopoulou, Bakker, Demerouti \& Schaufeli, 2009) and positive organisational behaviour, such as personal initiative and learning (Bakker \& Demerouti, 2008; Sonnentag, 2003). Given the meta-analytic relationship between employee engagement and indicators of performance such as customer satisfaction, turnover, safety and productivity (Harter, Schmidt \& Hayes, 2002), organisations are realising the importance of employee engagement in contributing to the sustainment of their competitive edge in the global market (Schabracq \& Cooper, 2000).

Positive organisational behaviour (POB) is defined as: 'the study and application of positively oriented human resource strengths and psychological capacities that can be measured, developed, and effectively managed for performance improvement in today's workplace' (Luthans, 2002a, p. 59). Luthans and colleagues have offered evidence that dimensions of $\mathrm{POB}$ are indeed open to development and, importantly, related to performance (Luthans, Avey \& Patera, 2008; Luthans, Avey, Avolio \& Peterson, 2010; Peterson, Luthans, Avolio, Walumba \& Zheng, 2011). Bakker and Demerouti (2007) have advanced that such employee positive psychological resources should buffer against the effects of stress, whilst Avey, Luthans, and Jensen (2009) provide some empirical evidence for this combative effect. Xanthopoulou, Bakker, Demerouti \& Schaufeli (2007) also illustrate that personal resources could mediate between job resources and work engagement. Conceptually, Sweetman and Luthans (2010) advance that employee PsyCap, as an indicator of POB, can be thought of as a job resource that should help individual employees to obtain goals, buffer demands and facilitate personal growth. What is still lacking is a thorough understanding of the interaction of PsyCap and work engagement.

\section{Research purpose}

The focus on $\mathrm{POB}$ as a specific approach to employee management has a positive impact on human resource development and performance management; it is also an important means to equip today's employees with the personal skills to deal with the challenges of working life, because the investment in human capital seems to be vital to ensure organisational success (Luthans, Norman, Avolio \& Avey, 2008). POB is deemed open to development with highly focused training interventions (Luthans, 2002a; Luthans et al., 2004; Youssef \& Luthans, 2007), including taskmastery experiences, positive role modelling, goal setting, contingency planning and social support activities (Luthans, Avey, Avolio, Norman \& Combs, 2006; Luthans, Youssef \& Avolio, 2007; Luthans, Avey \& Patera, 2008).

The focus of POB research and theory falls on four statelike psychological capacities that constitute a higher-order construct: psychological capital (PsyCap), consisting of hope, optimism, resiliency and self-efficacy (Luthans et al., 2004). It has conceptually and empirically been shown that PsyCap is the underlying second order construct, with better predictive power than any of the individual constructs (Luthans, Avolio, Avey \& Norman, 2007). Work engagement is considered by Bakker and Demerouti (2008, p. 209) to be 'a positive, fulfilling, work-related state of mind' predicted by job and personal resources (e.g. optimism, self-efficacy and self-esteem). The purpose of this research was to empirically investigate the relationship between PsyCap and work engagement, over time.

\section{Trends from the research literature}

Work engagement is aligned with $\mathrm{POB}$, as both engagement and the facets of $\mathrm{POB}$ are considered to be state-like positive psychological capacities (Bakker et al., 2008; Youssef \& Luthans, 2007). Engagement is, however, considered to be more stable and longer lasting (Hallberg \& Schaufeli, 2006). Engaged employees use resources such as optimism, selfefficacy, resilience and an active coping style to assist them to manage and influence their work environment with more success (Bakker \& Demerouti, 2008; Luthans, Norman, Avolio \& Avey, 2008). Both PsyCap and engagement are also known to have a relationship with and impact on organisational behaviours and outcomes (Bakker \& Demerouti, 2008; Stajkovic \& Luthans, 1998). In their meta-analysis, Avey, Reichard, Luthans and Mhatre (2011) illustrate that PsyCap relates positively to attitudes such as job satisfaction, organisational commitment and psychological well-being at work, and negatively to employee cynicism, turnover, stress and anxiety. It also relates positively to employee behaviours such as organisational citizenship and negatively to deviance. Engagement has been shown through meta-analysis to relate to indicators of performance such as customer satisfaction, turnover, safety and productivity (Harter et al., 2002). Moreover, in research conducted by Bakker, Gierveld and Van Rijswijk (2006), employees who used their resources optimally scored the highest in engagement; the researchers concluded that optimism, self-efficacy and resilience contribute specifically to engagement.

Luthans (2002a) makes it clear that PsyCap is measurable, is based on sound theory and research and is clearly differentiable from populist positively orientated personal development approaches. Its developmental nature requires the PsyCap construct to be potentially state-like and therefore rules out the fixed trait-like personality, attitudinal and motivational variables associated with traditional organisational behaviour. This positive approach could therefore be applied to organisational behaviour as it supports a theory and research-driven point of view and methodology about old as well as new organisational behaviour concepts such as confidence, hope, optimism, happiness and resiliency (Luthans, 2002a; 2002b).

\section{Research objectives}

There is a well-established notion that investment in human capital is crucial for organisational success in the 
competitive modern business environment (Luthans \& Youssef, 2007). Luthans (2012) requires psychological capital to be open to development (i.e. state-like rather than traitlike), and to have a positive impact on especially employee performance, but also attitudes and behaviours. Similarly, engagement is conceptualised as being more state-like, and open to development (Schaufeli, Bakker \& Salanova, 2006). Both PsyCap and engagement are constructs that in their aggregate form are made up of positively orientated statelike constructs, which can be developed and could contribute to positive work outcomes. However, establishing the temporal order of these variables has not previously been possible with cross-sectional data. The objectives set for this research are therefore to establish if there is:

- A causal relationship between PsyCap at Time 1 and PsyCap at Time 2.

- A causal relationship between engagement at Time 1 and engagement at Time 2.

- An empirical relationship between PsyCap and engagement, and causality between these constructs.

\section{Contribution of the study}

Research to determine the relationship between PsyCap and engagement is important for both theoretical development and the management of quality of working life of employees. Meeting the research objectives could contribute to training programmes aimed at improving employees' work engagement and psychological capital. From a POB perspective, the investigation is important as Luthans (2002b, p. 698) argues that 'a proactive positive organisational behaviour approach' is what is needed for contemporary and global business to survive. From an engagement perspective, Brim and Asplund (2009) point out that research has indicated that customers experience poor service when they are served by disengaged employees. Salanova et al. (2005) point out that for service workers, work engagement forecasts a service climate, which in turn is indicative of performance by the employees and loyalty of customers. Engagement can therefore make a true difference to employers as it contributes to organisational effectiveness and may present a competitive advantage (Bakker et al., 2008). The question of how PsyCap and engagement relate to each other has remained mostly theoretical. The question concerning causality however has practical importance too, as this has a direct implication for future human resource development efforts (i.e. should we train to enhance PsyCap and facilitate engagement, or does engagement lead to PsyCap in the long term?). The objective of this study was to investigate the causal relationship and temporal order in the relationship between PsyCap and engagement with a longitudinal survey that tested the crosslagged effects between two measurements.

\section{Review of the literature}

Business environments are changing globally with subsequent changes in the psychological contract between employees and employers (Rothmann \& Joubert, 2007). South Africa is not excluded from these challenges and South
African organisations experience increasing pressure to improve their performance and sustain their competitiveness (Coetzee \& De Villiers, 2010). Maslach, Schaufeli and Leiter (2001) and Luthans et al. (2004) point out that more is expected of employees in terms of time, effort, knowledge, skill, innovation, flexibility and speed-to-market, whilst job security, career opportunities and lifetime employment are deteriorating.

Although work is an economic activity, most people regard it as more than just an activity to provide $n$ their daily livelihood. Recent studies (Fields, Wilder, Bunch \& Newbold, 2008) suggest that especially younger (Generation $X$ and Millennial) employees seek more than just a pay cheque. In addition to work being an important source of people's economic livelihood, being employed can also be seen as contributing significantly to people's identity (Ibarra, 2002). Although employees are therefore looking to do well and thrive and want to be completely engaged in their work (Loehr \& Schwartz, 2003), research indicates that only 31\% of employees worldwide are engaged, whilst $17 \%$ are actually disengaged (Blessingwhite Research, 2011).

\section{Work engagement}

Research has now clearly established the energy and identification dimensions of employees' work experience as described by the burnout and engagement phenomena (Schaufeli \& Bakker, 2013; Demerouti, Mostert \& Bakker, 2010; Gonzaléz-Roma, Schaufeli, Bakker \& Llorets, 2006; Xanthopoulou, Bakker, Kantas \& Demerouti, 2012). Bakker et al. (2007) and Demerouti et al. (2010) concluded that exhaustion and vigour likely represent separate energy constructs, whilst cynicism and dedication can rather be thought of as opposite ends of the continuum.

Most researchers agree that engaged employees reflect high levels of energy and a strong identification with their work (Bakker et al., 2008). Engagement is seen as developing from a perspective of positive psychology as it also focuses on human strengths and optimal performance rather than on weaknesses and malfunctioning (Seligman \& Csikszentmihalyi, 2000). It is also regarded as a positive organisational behaviour construct (Bakker \& Demerouti, 2008).

According to Hallberg and Schaufeli (2006), engagement stresses the notion of positive attachment and optimal performance in the work environment in terms of well-being, with high levels of energy, involvement and commitment invested in one's work. Engagement is thus a positive, workrelated state of well-being or fulfilment, where engaged employees have high levels of energy, are enthusiastic about and show strong identification with their work (Bakker et al., 2008; Maslach et al., 2001). Engagement is thus a positive experience in itself (Schaufeli, Salanova, González-Romá \& Bakker, 2002) and able to facilitate job and personal resources (Bakker \& Demerouti, 2007; Hakanen, Schaufeli \& Ahola, 2008). It is further associated with employees who are strongly attached to their work roles, by being physically 
involved, cognitively vigilant and performing their tasks with total emotional involvement (Coetzee \& De Villiers, 2010), and who are prepared to go above and beyond typical in-role performance (Macey \& Schneider, 2008). Furthermore, engaged employees view themselves as capable of handling their job demands successfully (Schaufeli et al., 2006), contributing to higher levels of productivity and profitability, increased safety, greater attendance and retention (Fleming \& Asplund, 2007).

\section{Positive organisational behaviour}

Luthans (2002a, 2002b) initially applied ideas emanating from positive psychology to the workplace in his conceptualisation of POB, and refined his ideas into the more specific PsyCap soon thereafter (Luthans et al., 2004; Luthans \& Youssef, 2004; Luthans, Youssef \& Avolio, 2007). Positive organisational behaviour is reconcilable with positive psychology, because positive psychology emphasises the study of human strengths and virtues, with the aim of understanding and facilitating positive developmental outcomes (Seligman \& Csikszentmihalyi, 2000). POB is intended to focus on a positive approach to developing and managing human resources in the modern work environment (Gardner \& Schermerhorn, 2004; Luthans, Avolio, Avey \& Norman, 2007).

According to Luthans (2002a, 2002b) and Luthans and Youssef (2007), POB can be managed successfully to ensure an improvement in employees' performance. The principle contribution of $\mathrm{POB}$ furthermore lies in the fact that it is generative and contributes to optimal functioning (Luthans et al., 2004), in the sense that the application of positive psychology in the workplace, as POB, emphasises the significance of a positive approach (Youssef \& Luthans, 2007).

\section{Theoretical positioning}

The Conservation of Resources theory ([COR]; Hobfoll, 2001; 2002) sees the attainment and preservation of resources as the prime human motivation. Individuals seek to obtain resources, but also to apply them in life. The COR has been used to describe the functioning of PsyCap as a higher-order construct, consisting of its constituent dimensions of hope, optimism, resilience and efficacy (Avey et al., 2011). The COR also conceptualises 'gain spirals' (Hobfoll \& Shirom, 2000), where positive reciprocal relationships exist between positively oriented individual states. This idea of gain spirals is also used to explain the better predictive power of the second order construct of PsyCap, compared to any of the individual constructs of hope, optimism, resilience and efficacy (Luthans, Avolio, Avey \& Norman, 2007; Sweetman \& Luthans, 2010).

Engagement is most often conceptualised within the Jobdemands Resources theory ([JD-R]; Demerouti, Bakker, Nachreiner \& Schaufeli, 2001). Within this theory, job demands are seen as contributing to burnout, whilst job resources are seen as contributing to work engagement. In turn, burnout relates to negative individual and organisational outcomes, whilst engagement is seen as the antecedent of positive outcomes (Bakker \& Demerouti, 2007).

In line with the idea of gain spirals, Sweetman and Luthans (2010, p. 57) conceptualise the relationship between PsyCap and work engagement as being reciprocal. Specifically, they theorise that vigour will be relating to 'efficacy in motivating the effort, hope in providing the willpower and developing alternative pathways to achievement, optimism in expecting future success and resiliency in the continued pursuit of goals', and dedication to 'the efficacy related to involvement in one's work, optimism in attributions of significance and pride, hope in dedicated waypower and pathways, and resiliency in continuing in the face of challenging obstacles and adversity'. Absorption is seen to relate mostly to efficacy, optimism and resiliency (Sweetman \& Luthans, 2010). Conversely, they also see efficacy and resiliency as contributing to all three dimensions of work engagement, optimism to dedication and absorption, and hope to vigour and dedication. Bakker et al. (2007) theorise that the relationship between specifically self-efficacy and employee well-being may be reciprocal.

The above has, to our knowledge, received limited attention from researchers. Xanthopoulou et al. (2007) illustrated that personal resources (in their case, self-efficacy, organisationalbased self-esteem and optimism) partially mediated between job resources and work engagement. Luthans (2012) and colleagues (Avey, Luthans \& Mhatre, 2008; Avey et al., 2011; Sweetman \& Luthans, 2010) have called for more research into the antecedents of PsyCap, and specifically longitudinal research to advance the understanding of the interaction between PsyCap and work engagement. The latter is precisely what we address in this investigation.

\section{Research design}

The research will investigate the hypothesised model shown in Figure 1.

\section{Research approach}

The researchers made use of a quantitative, longitudinal research design that tested the cross-lagged effects between two measurements. A longitudinal cross-lagged panel design requires the same participants to be assessed on the

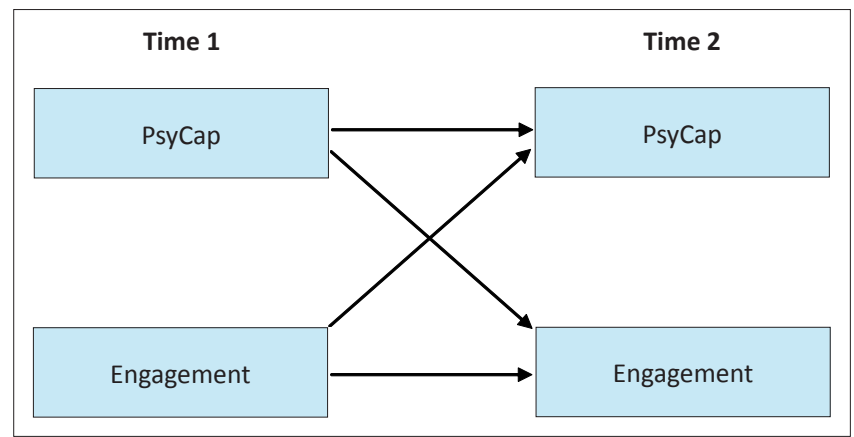

FIGURE 1: Hypothesised research model of the causal relationship between psychological capital and engagement. 
same variables over time. A cross-lagged analysis makes it possible to investigate the temporal precedence of the cause, which is a necessary condition for causal inference (Cook \& Campbell, 1979). The temporal order between PsyCap and engagement was investigated by means of structural equation modelling. Primary data was gathered by means of a penand-paper survey, and variables were represented by items on Likert-type scales, with items construing dimensions, and dimensions summing to represent constructs.

\section{Research method}

\section{Research participants}

During the first measurement (Time 1), surveys were distributed to all 1003 permanent employees working in all departments across all units of the particular business unit, which forms part of a larger chemical factory. A total of 908 completed questionnaires were returned and only 892 of the questionnaires could be used, representing a return rate of $88.9 \%$. During the second measurement (Time 2), 915 questionnaires were distributed to the same study population as in the first measurement. A total of 358 completed questionnaires were returned which represented a response rate of $39.1 \%$. When matching participants from the pre- to the post-measurement was done, only 163 respondents could be matched, representing a response rate of $17.8 \%$ (compared to the original 915 potential respondents) of useable data for the longitudinal study.

The results presented below are based on longitudinal data for 163 respondents. The characteristics of these participants are reported in Table 1.

Table 1 indicates that the majority of participants represented in the study population were men, which reflects the demographics of the organisation very well, given the fact that the technical, maintenance and operational areas of the organisation are still dominated by men. The race groups are also representative of the actual population of the organisation with the majority of the participants represented

TABLE 1: Characteristics of the participants (longitudinal sample; $n=163$ ).

\begin{tabular}{lll}
\hline Category & $\boldsymbol{f} \dagger$ & $\% \dagger$ \\
\hline Gender & 50 & 30.67 \\
Female & 113 & 69.33 \\
Male & & \\
Race & 53 & 32.52 \\
Black & 4 & 2.45 \\
Indian & 105 & 64.42 \\
White & & \\
Job level & 1 & 0.61 \\
Middle management (Level 5) & 13 & 7.98 \\
Middle management (Level 5 and Level 6) & 12 & 7.36 \\
Supervisors (Level 6) & 42 & 25.77 \\
Supervisors (Level 7) & 41 & 25.15 \\
Skilled workers (Level 8) & 30 & 18.41 \\
Skilled workers (Level 9) & 22 & 13.50 \\
Skilled workers (Level 10) & 1 & 0.61 \\
Semi-skilled workers (Level 11) & 1 & 0.61 \\
Semi-skilled workers (Level-12) &
\end{tabular}

$f$, frequency.

$\dagger$, Where totals do not add up to 100 , it is due to missing values. in the White group. The average age of respondents was 40.4 years ( $\mathrm{SD}=11.16$ years) and with regard to the years of service, the average tenure was 13.4 years $(\mathrm{SD}=10.35$ years). The majority of the participants $(91.4 \%)$ were on supervisory and non-managerial levels.

\section{Measuring instruments}

The following measuring instruments were used in the empirical study:

The Utrecht Work Engagement Scale (UWES): The UWES (Schaufeli \& Bakker, 2003) was used to measure the levels of engagement of the participants. The UWES includes three dimensions: vigour, dedication and absorption. Consistent with current thinking and practice, we opted to evaluate only the core dimensions of engagement, that is, vigour and dedication (Brand-Labuschagne, Mostert, Rothmann \& Rothmann, 2012; Demerouti et al., 2010; Schaufeli \& Bakker, 2013; Gonzaléz-Roma et al., 2006; Xanthopoulou et al., 2012). The factorial validity, construct equivalence, internal consistency (reliability) and stability of the UWES have been confirmed in various international (Schaufeli \& Bakker, 2003; Schaufeli et al., 2002) and South African studies (Coetzee \& De Villiers, 2010; Jackson, 2004; Storm \& Rothmann, 2003). Responses are on a five-point Likert scale, ranging from 1 ('strongly disagree') to 5 ('strongly agree'). A high score reflects high levels of engagement. A typical question for the vigour dimension, which has six questions, is: 'I am bursting with energy in my work'. A typical question for the dedication dimension, which has five questions, is: 'My job inspires $m e^{\prime}$. The alpha coefficients for the three subscales varied between 0.80 and 0.90 (Schaufeli \& Bakker, 2003). Storm and Rothmann (2003) obtained the following alpha coefficients for the UWES in a sample of 2396 members of the South African Police Service: vigour: 0.78, dedication: 0.89. Coetzee and De Villiers (2010) obtained alpha coefficients of 0.77 and 0.88 for vigour and dedication in a financial institution.

A measure of PsyCap, derived from the four constructs (hope, optimism, self-efficacy and resilience) that form the PsyCap Scale (Luthans, 2002a), was constructed and validated in the current sample (De Waal, 2011). The three items that represented the respective individual scales best, based on factor analytic results, were taken to form the new scale. A reliability coefficient of 0.69 was obtained in the South African sample, and the factor structure was established with confirmatory factor analysis. Response options were also on a five-point Likert scale, ranging from 1 ('strongly disagree') to 5 ('strongly agree').

A biographical questionnaire was developed to gather information regarding the demographic characteristics of the participants. Information gathered included age, gender, race, job level and specific work function in the business under investigation, as well as years employed in the organisation.

\section{Research procedure}

For practical reasons, data gathering for the first measurement (Time 1) took place once a week over a period of 14 months 
(from August 2007 to September 2008), as part of an internal training opportunity. During the second measurement (Time 2), questionnaires were handed out to employees in their work environment. They were then allowed two weeks in April 2009 to complete the questionnaires. This implies that the longest period from initial evaluation to re-evaluation was 21 months (from August 2007 to April 2009) and the shortest period seven months (from September 2008 to April 2009).

\section{Statistical analysis}

Current debate exists about more traditional, 'frequentist' approaches to statistical analysis, especially in psychology (Bem, Utts \& Johnson, 2011; Lee \& Wagenmakers, 2005; Wagenmakers, Wetzels, Borsboom \& Van der Maas, 2011, Van de Schoot, Hoijtink \& Jan-Willem, 2011). Wagenmakers et al. (2011) argue for the use of a Bayesian statistical approach, whilst other authors (Bem et al., 2011) are more moderate in their view, considering both approaches as applicable. However, said authors also note the intrinsic subjectivity in statistical model building, and consider specifying a prior distribution informative. Van de Schoot et al. (2011, p. 1) have called for a move from the traditional approach of rejecting the null hypothesis to the 'informative' hypothesis. This is also termed the 'specified experimental hypothesis' (Bem et al., 2011, p. 716). This approach hails from Bayesian statistical methodology and, in layman's terms, allows researchers to account for what is already known. A Bayesian approach allows for accounting for existing knowledge in model-building, or alternatively stated, 'data-driven model building' (Vrieze, 2012, p. 233). The Bayesian view is in fact that model parameters should be considered as random variables themselves, but with a probability distribution that may be informed by the true unknown fixed parameter values (cf. Vrieze, 2012). Especially with small sample sizes, as is the case in our analysis, there is less certainty that confidence intervals will have good coverage and that point distributions are unbiased (Asparouhov \& Muthén, 2010). The Bayesian approach can effectively deal with any sample size (Lee \& Wagenmakers, 2005). In combination with equality constraints, this approach allows for a parametric bootstrap imposed on regression coefficients. Van de Schoot and Strohmeier (2011) have illustrated this approach to yield gain in statistical power. The most commonly used model selection procedures are the Akaike information criterion (AIC), Bayesian information criterion (BIC) and the deviance information criterion ([DIC]; Van de Schoot et al., 2011). Here, we have opted to employ the BIC. Vrieze (2012) has presented some evidence that, especially in small samples, and with less complicated models, the BIC may be more appropriately used.

The Mplus 7.11 was used for the analyses (Muthén \& Muthén, 2013). The Bayesian estimator as implemented in Mplus was used for estimation. After estimation, parameter trace plots and kernel density plots were inspected to confirm mixing (Asparouhov \& Muthen, 2010). Descriptive statistics (e.g. means, standard deviations, skewness and kurtosis) and inferential statistics (e.g. correlation analyses) were used to analyse the data. Cronbach alpha coefficients were employed to determine the internal consistency, homogeneity and unidimensionality of the measuring instruments (Clark \& Watson, 1995). Pearson's product-moment correlation coefficients were used to specify the relationship between the variables. Effect sizes (Steyn, 1999) served to decide on the practical significance of the findings.

A cross-lagged model was used to examine the temporal order in the relationship between PsyCap and engagement. Cross-lagged models enable the researcher to examine the temporal order in the relationships between the variables (Cook \& Campbell, 1979). The first model (M1) includes only effects between the variables measured at Time 1 and Time 2 to establish the extent to which variables at Time 1 are predictive of (the same) variables at Time 2 . The second model (M2) analyses the effect of PsyCap at Time 1 to work engagement at Time 2. The third model (M3) analyses the effect of work engagement at Time 1 to PsyCap at Time 2. Lastly, the fourth model (M4) analyses both effects simultaneously.

\section{Results}

The first step in our analysis focused on finding the best fitting measurement model. Based on the larger Time 1 sample, we tested competing measurement models with confirmatory factor analysis, with a Bayesian estimator. Three models were compared using the BIC. Results are presented in Table 2.

The BIC values reported in Table 2 indicate that the model in which both engagement and PsyCap are represented by one-factor models best represents the data, given fit and parsimony. Subsequent analyses are based on this model.

Next, (in Table 3) we report item loadings for the various items that represented the model.

The factor loadings and intercepts reported in Table 3 became the informative priors in the longitudinal measurement model. Residual variances were specified with noninformative priors (Mplus default). Loadings, intercepts and variances were parameterized to be equal across time points. Thus, the measurement model was assumed to be invariant across time points. This was assumed and not tested, because of the small sample size.

Descriptive statistics, Cronbach's alpha coefficients and the correlation coefficients between PsyCap and work engagement dimensions $(n=163)$ obtained at both measurements (Time 1 and Time 2) of the longitudinal study are reported in Table 4.

TABLE 2: Comparison of measurement models using the Bayesian information criterion (BIC).

\begin{tabular}{ll}
\hline Model & BIC \\
\hline One-factor engagement, one-factor PsyCap & 46695.517 \\
One-factor engagement, four-factor PsyCap & 46746.365 \\
Two-factor engagement, four-factor PsyCap & 46772.332 \\
\hline
\end{tabular}

PsyCap, psychological capital. 


\begin{tabular}{|c|c|c|c|c|}
\hline Item & $\begin{array}{l}\text { Unstandardised } \\
\text { loading }\end{array}$ & $\begin{array}{l}\text { Standardised } \\
\text { loading }\end{array}$ & Intercept & $\begin{array}{l}\text { Residual } \\
\text { variance }\end{array}$ \\
\hline \multicolumn{5}{|l|}{ Engagement } \\
\hline I am bursting with energy in my work & 1 & 0.607 & 3.546 & 0.632 \\
\hline I feel strong and vigorous in my job & 0.68 & 0.453 & 3.998 & 0.725 \\
\hline When I get up in the morning, I feel like going to work & 1.249 & 0.777 & 4.204 & 0.795 \\
\hline In my job, I can continue working for very long periods at a time & 0.477 & 0.275 & 3.965 & 0.946 \\
\hline I am very resilient, mentally, in my job & 0.519 & 0.335 & 3.671 & 0.585 \\
\hline I find my work full of meaning and purpose & 0.755 & 0.524 & 4.804 & 0.615 \\
\hline I am enthusiastic about my job & 0.341 & 0.233 & 3.057 & 0.924 \\
\hline My job inspires me & 1.057 & 0.644 & 5.463 & 0.799 \\
\hline I am proud of the work that I do & 0.865 & 0.62 & 3.363 & 0.888 \\
\hline To me, my work is challenging & 0.559 & 0.448 & 4.076 & 0.765 \\
\hline \multicolumn{5}{|l|}{ PsyCap } \\
\hline In uncertain times, I usually expect the best (Optimism 1) & 1 & 0.435 & 4.877 & 0.81 \\
\hline I'm always optimistic about my future (Optimism 4) & 1.444 & 0.572 & 4.611 & 0.673 \\
\hline When I make plans, I am certain I can make them work (Self-efficacy 1) & 1.149 & 0.551 & 5.862 & 0.696 \\
\hline Failure just makes me try harder (Self-efficacy 13) & 1.249 & 0.569 & 5.366 & 0.677 \\
\hline When I have something unpleasant to do, I stick to it until I finish it (Self-efficacy 8) & 1.092 & 0.444 & 4.599 & 0.803 \\
\hline I energetically pursue my goals (Hope 2 ) & 1.171 & 0.53 & 5.236 & 0.719 \\
\hline I can think of many ways to get the tings in life that are most important to me (Hope 6) & 1.371 & 0.56 & 4.674 & 0.686 \\
\hline Even when others get discouraged, I know I can find a way to solve the problem (Hope 8) & 1.256 & 0.619 & 5.784 & 0.616 \\
\hline I enjoy dealing with new and unusual situations (Resiliency 3) & 1.293 & 0.536 & 4.833 & 0.713 \\
\hline I would be willing to describe myself as a pretty 'strong' personality (Resiliency 13) & 1.286 & 0.627 & 5.96 & 0.607 \\
\hline I usually succeed in making a favourable impression on people (Resiliency 4) & 1.127 & 0.533 & 5.452 & 0.716 \\
\hline
\end{tabular}

PsyCap, psychological capital.

TABLE 4: Descriptive statistics, Cronbach alpha coefficients and correlation of the measuring instruments for both Time 1 and Time 2.

\begin{tabular}{|c|c|c|c|c|c|c|c|c|c|c|c|c|}
\hline \multirow[t]{2}{*}{ Variable } & \multicolumn{2}{|c|}{$M$} & \multicolumn{2}{|c|}{ SD } & \multicolumn{2}{|c|}{ Skewness } & \multicolumn{2}{|c|}{ Kurtosis } & \multicolumn{2}{|c|}{$\alpha$} & \multicolumn{2}{|c|}{$r$} \\
\hline & T1 & T2 & T1 & $\mathrm{T2}$ & T1 & T2 & T1 & T2 & T1 & T2 & $\mathrm{T} 1$ & T2 \\
\hline Work engagement & 3.64 & 3.49 & 0.50 & 0.54 & -0.46 & -0.60 & $1.56^{\mathrm{a}}$ & $1.04^{\mathrm{a}}$ & 0.88 & 0.89 & $0.43^{\mathrm{b} *}$ & - \\
\hline PsyCap & 3.83 & 3.78 & 0.40 & 0.34 & 0.34 & 0.55 & 0.13 & $1.00^{\mathrm{a}}$ & 0.69 & 0.63 & - & $0.34^{\mathrm{b} *}$ \\
\hline
\end{tabular}

M, mean; SD, standard deviation; $\alpha$, alpha; $r$, Pearson's correlation.

a, High skewness and/or kurtosis.

b, $r \geq 0.30$ (practically significant) (medium effect).

$*, p \leq 0.01$ (statistically significant).

TABLE 5: Model comparison.

\begin{tabular}{ll}
\hline Model & BIC \\
\hline Stability & 16935.407 \\
PsyCap (T1) > Work engagement (T2) \& stability & 16931.906 \\
Work engagement (T1) > PsyCap (T2) \& stability & $\mathbf{1 6 9 2 7 . 4 0 0}$ \\
Full cross-lagged \& stability & 16940.161 \\
\hline
\end{tabular}

PsyCap, psychological capital; T1, Time 1; T2, Time 2; BIC, Bayesian information criterion.

As indicated in Table 4, the work engagement measure shows positive kurtosis at Time 1 and Time 2, whilst the PsyCap measure shows positive kurtosis at Time 2. The PsyCap measure presents with lower reliability scores, whilst work engagement indicates excellent reliability. Time 1 and Time 2 data indicate a positive practically significant correlation of medium effect between PsyCap and work engagement.

The final step in our analysis was to estimate the most appropriate structural model, given the available data. We compared models in a cross-lagged fashion (see Table 5).

It is seen in Table 5 that the structural model that best fits the data is the model that allows stability as well as significant effects from work engagement at Time 1 to PsyCap at
Time 2, based on the BIC values. To follow, in Table 6, we report descriptive values for the best fitting model.

It is seen in Table 6 that the work engagement (T1) > PsyCap (T2) model has a standardised beta value of 0.195 . The credibility interval remains positive.

\section{Discussion}

The objective of this study was to conceptualise and investigate the causal relationship and temporal order in the relationship between PsyCap and work engagement with a longitudinal survey and cross-lagged research design.

As indicated by the correlations, the relationship between PsyCap and work engagement was positive for both Time 1 and Time 2. This finding is in line with other research (Simbula, Guglielmi \& Schaufeli, 2011). The use of a longitudinal research design that tested the cross-lagged effects between the two measurements yielded an important new finding in the understanding of the relationship between PsyCap and engagement in this specific study population. Results revealed that PsyCap at Time 1 did not predict engagement 
TABLE 6: Fit values for the work engagement (T1) > PsyCap (T2) \& stability model.

\begin{tabular}{lllll}
\hline Variable & Standardised beta & SD of estimate & One tailed $\boldsymbol{p}(<\mathbf{0 . 0 2 5})$ & Lower credibility interval (95\%) \\
\hline PsyCap (T2) & & & & Upper Cl \\
PsyCap (T1) & 0.608 & 0.072 & 0 & 0.453 \\
Work engagement (T1) & 0.195 & 0.087 & 0.012 & 0.024 \\
Work engagement (T2) & & & & 0.729 \\
Work engagement (T1) & 0.598 & 0.064 & 0 & 0.468 \\
\hline
\end{tabular}

PsyCap, psychological capital; T1, Time 1; T2, Time 2.

at Time 2. Evidence was found, however, that engagement at Time 1 predicted PsyCap at Time 2. Our findings therefore are most consistent with suggestions that work engagement can facilitate the mobilisation of job and personal resources (Bakker \& Demerouti, 2007; Hakanen et al., 2008). Cordery (2007) also found engagement to be a strong predictor of hope, optimism and self-efficacy. Our results did not indicate a significant effect of PsyCap on work engagement, over time, which is in opposition to Bakker, Gierveld and Van Rijswijk (2006), who found that optimism, self-efficacy and resilience contributed to engagement.

Although PsyCap is associated with personal resources, and engagement with work-related phenomena, engagement predicted PsyCap, which could theoretically be understood with the idea of gain spirals, as postulated in the Conservation of Resources theory (Hobfoll, 2001; 2002). Within this framework, the current results are taken to indicate that work engagement facilitates the building of PsyCap. Admittedly, the additional illustration of the interaction of PsyCap with work engagement over time would have been stronger proof of a reciprocal relationship. A possible interpretation of this finding is that individuals are more actively engaged in daily working life than in actively building personal resources (i.e. PsyCap). Taking a more pragmatic view, this also makes sense: work is a major factor through which individuals not only sustain their lives, but also construct their identities (Ibarra, 2002). Bakker, van Emmerik and Euwema (2006) have also described the crossover phenomenon, which implies that an individual's working life should not be considered as an isolated phenomenon, separate from the rest of their life experience. It is conceivable that positive, work-related resources such as work engagement should affect the individual over time to such an extent that it has an impact on their personal resources (PsyCap). We could advance here that based on these assumptions, the relationship over time from work engagement to PsyCap should at least be stronger, compared to the relationship over time from PsyCap to work engagement. This finding further highlighted the importance of investigating possible ways of promoting work engagement in the working environment.

\section{Limitations}

We found that one-factor models of our variables of interest (i.e. PsyCap and work engagement) best fit the data. Although this view on the variables is defensible, with PsyCap and work engagement both presenting second-order constructs construed of sub-dimensions, it did limit us in terms of our investigation of the relation between the respective subdimensions. What we thus represent here is a limited view on super-order level and intricacies of the relationship between sub-dimensions may have been overlooked.

Due to practical constraints, the time lag between our first and second data gatherings is unequal. The longest period from the first measurement to re-evaluation was 21 months, and the shortest period seven months. The extended period in which the data was collected and the differences in time lag could have influenced the results. Although the longitudinal design is also a strong point of this study, the influence of the variance from initial to reassessment has not been accounted for. Also, our choice of fit statistic (BIC) may be insensitive to smaller effects (cf. Vrieze, 2012).

The present study has been limited to participants employed in a specific division of a large chemical plant and the findings can therefore not be readily generalised to other occupational groupings in the particular manufacturing facility, or other organisational contexts. Indeed the mostly highly technical nature of the work performed may be deemed supportive of our finding that the relationship from work engagement to PsyCap is strongest over time, in the sense that mastering complex tasks may contribute directly to building personal PsyCap. Similar investigations would therefore have to be conducted in other organisations to verify these findings and to make more general conclusions concerning the relationship between constructs measured in this study.

\section{Suggestions for future research}

We must note that our view of the relationship between these variables was very limited, in the sense that we did not consider any antecedents or outcome variables. Although we took a very narrow focus on the relationship between PsyCap and work engagement, more work with larger models is indicated. Also, future researchers would do well to investigate cross-lagged effects between such antecedents and outcomes and the dimensions of PsyCap and work engagement.

Our results indicate that the relationship between work engagement and PsyCap over time may be stronger than the inverse relationship, at least in this sample. However, to truly illustrate this relationship, and specifically test for the possible reciprocal nature thereof, one would need to test these relationships with multiple data points. 


\section{Conclusion}

The management of employee engagement is again highlighted here. Job resources such as social support from colleagues and supervisors, performance feedback, opportunities to apply a wide variety of skills and tasks, autonomy, learning and development opportunities, coaching and positive work experiences are all positively related to engagement (Bakker \& Demerouti, 2008; Koyuncu, Burke \& Fiksenbaum, 2006; Schaufeli \& Bakker, 2003), and are noted as avenues for possible intervention in facilitating employee engagement. Closely related, PsyCap can be enhanced through task-mastery experiences, positive role modelling, goal setting, contingency planning and social support activities (Luthans, Youssef 2007; Luthans et al., 2008). Managers tasked with developing employees would do well to incorporate such activities into their employee training and development initiatives.

\section{Acknowledgements Competing interest}

The authors declare that they have no financial or personal relationship(s) that may have inappropriately influenced them in writing this article.

\section{Authors' contributions}

Both authors developed the idea for the article. J.J.d.W. (North-West University) developed an earlier version of this article as part of his PhD. J.P. (North-West University) saw it through the publication process.

\section{References}

Asparouhov, T., \& Muthén, B. (2010). Bayesian analysis of latent variable models using Mplus (Version 4). Retrieved July 28, 2013, from http://statmodel.com/ download/BayesAdvantages6.pdf

Avey, J.B., Luthans, F., \& Jensen, S.M. (2009). Psychological capital: A positive resource for combating employee stress. Human Resource Management, 48(5), 677-693. http://dx.doi.org/10.1002/hrm.20294

Avey, J.B., Luthans, F., \& Mhatre, K.H. (2008). A call for longitudinal research in positive organizational behavior. Leadership Institute Faculty Publications. Pape 7. Retrieved July 28,2013 , from http://digitalcommons.unl.edu/cgi/viewcontent. cgi $?$ article $=1006 \&$ context=leadershipfacpub

Avey, J.B., Reichard, R.J., Luthans F., \& Mhatre, K.H. (2011). Meta-analysis of the impact of positive psychological capital on employee attitudes, behaviors and performance. Human Resource Development Quarterly, 22, 127-152. http:// dx.doi.org/10.1002/hrdq.20070

Bakker, A.B., \& Bal, P.M. (2010). Weekly work engagement and performance: A study among starting teachers. Journal of Occupational and Organizational Psychology, 83, 189-206. http://dx.doi.org/10.1348/096317909X402596

Bakker, A.B., \& Demerouti, E. (2007). The Job Demands-Resources model: State of the art. Journal of Managerial Psychology, 22, 309-328. http://dx.doi. org/10.1108/02683940710733115

Bakker, A.B., \& Demerouti, E. (2008). Towards a model of work engagement. Career Development International, 13(3), 209-223. http://dx.doi. org/10.1108/13620430810870476

Bakker, A.B., Gierveld, J.H., \& Van Rijswijk, K. (2006), Succesfactoren bij vrouwelijke schoolleiders in het primair onderwijs: Een onderzoek naar burnout, bevlogenheid en prestaties [Success factors among female school principals in primary teaching: A study on burnout, work engagement, and performance]. Diemen: Right Management Consultants.

Bakker, A.B., \& Schaufeli, W.B. (2008). Positive Organisational Behavior: Engaged employees in flourishing organizations. Journal of Organizational Behavior, 29, 147-154. http://dx.doi.org/10.1002/job.515

Bakker, A.B., Schaufeli, W.B., Demerouti, E., \& Euwema, M.C. (2007). An organisational and social psychological perspective on burnout and work engagement. In K van den Bos, M. Hewstone, J. de Wit, H. Schut, \& M. Stroebe (Eds.), The scope of social psychology: Theory and applications (pp. 229-252). Oxford: Psychology Press.
Bakker, A.B., Schaufeli, W.B., Leiter, M.P., \& Taris, T.W. (2008). Work engagement: An emerging concept in occupational health psychology. Work and Stress, 22(3), 187-200. http://dx.doi.org/10.1080/02678370802393649

Bakker, A.B., Van Emmerik, H., \& Euwema, M.C. (2006). Crossover of burnout and engagement in workteams. Work and Occupations, 33(4), 464-480. http://dx.doi. org/10.1177/0730888406291310

Bem, D.J., Utts, J., \& Johnson, W.O. (2011). Must psychologists change the way they analyze their data? Journal of Personality and Social Psychology, 101(4), 716-719. http://dx.doi.org/10.1037/a0024777, PMid:21928916

Blessingwhite Research. (2011). Global employee engagement report. Beyond the numbers: A practical approach for individuals, managers and executives. Research report. Princeton, $\mathrm{NJ}$.

Brand-Labuschagne, L., Mostert, K., Rothmann, S. Jr, \& Rothmann, J.C. (2012). Burnout and work engagement of South African blue-collar workers: The development of a new scale. Southern African Business Review, 16(1), 58-93.

Brim, B., \& Asplund, J. (2009). Driving engagement by focusing on strengths. Retrieved November 16, 2009, from http://www.gmj.gallup.com/content/124214/DrivingEngagement-Focusing-Strengths.aspx

Clark, L.A., \& Watson, D. (1995). Constructing validity: Basic issues in objective scale development. Psychological Assessment, 7(3), 309-319.

Coetzee, M., \& De Villiers, M. (2010). Sources of job stress, work engagement and career orientations of employees in a South African financial institution. Southern African Business Review, 14(1), 27-57.

Cook, T.D., \& Campbell, D.T. (1979). Quasi-experimentation: Design and analysis issues for field setting. Chicago: Rand McNally.

Cordery, J. (2007). Accentuating the positive. Building hope, optimism, confidence and resilience in organisations. Survey results. Wembley, Western Australia: Australian Institute of Management.

De Waal, J.J.P. (2011). The role of Positive Organisational Behaviour in employee selfdevelopment and organisational outcomes. Unpublished doctoral thesis, NorthWest University, Potchefstroom, South Africa.

Demerouti, E., Bakker, A.B., Nachreiner, F., \& Schaufeli, W.B. (2001). The job demandsresources model of burnout. Journal of Applied Psychology, 86, 499-512. http:// dx.doi.org/10.1037/0021-9010.86.3.499, PMid:11419809

Demerouti, E., Mostert, K., \& Bakker, A.B. (2010). Burnout and work engagement: A thorough investigation of the independency of both constructs. Journal of Occupational Health Psychology, 15(3), 209-222. http://dx.doi.org/10.1037/ a0019408, PMid:20604629

Fields, B., Wilder, S., Bunch J., \& Newbold, R. (2008). Millennial Leaders: Success stories from today's most brilliant Generation Y Leaders. Buffalo Grove, IL: Writers of the Round Table.

Fleming, J.H., \& Asplund, J. (2007). Human sigma: Managing the employee-customer encounter. New York: Gallup Press.

Gardner, W.L., \& Schermerhorn, J.R. Jr. (2004). Unleashing individual potential: Performance gains through positive organizational behavior and authentic leadership. Organizational Dynamics, 33(3), 270-281. http://dx.doi. leadership. Organizational Dy
org/10.1016/j.orgdyn.2004.06.004

Gonzaléz-Roma, V., Schaufeli, W.B., Bakker, A.B., \& Llorets, S. (2006). Burnout and work engagement: Independent factors or opposite poles? Journal of Vocational Behavior, 62, 165-174. http://dx.doi.org/10.1016/j.jvb.2005.01.003

Hakanen, J.J., Schaufeli, W.B., \& Ahola, K. (2008). The job demands-resources model: A three-year cross-lagged study of burnout, depression, commitment and work engagement. Work and Stress, 22, 224-241. http://dx.doi. org/10.1080/02678370802379432

Halbesleben, J.R.B., \& Wheeler, A.R. (2008). The relative roles of engagement and embeddedness in predicting job performance and intention to leave. Work \& Stress,22(3), 242-256. http://dx.doi.org/10.1080/02678370802383962

Hallberg, U.E., \& Schaufeli, W.B. (2006). 'Same same' but different? Can work engagement be discriminated from job involvement and organisational commitment? European Psychologist, 11(2), 119-127. http://dx.doi. org/10.1027/1016-9040.11.2.119

Harter, J.K., Schmidt, F.L., \& Hayes, T.L. (2002). Business-unit level relationship between employee satisfaction, employee engagement and business outcomes: A meta-analysis. Journal of Applied Psychology, 87, 268-279. http://dx.doi. org/10.1037/0021-9010.87.2.268

Hobfoll, S.E. (2001). The influence of culture, community, and the nested-self in the stress process: Advancing Conservation of Resources theory. Applied Psychology, 50(3), 337-421. http://dx.doi.org/10.1111/1464-0597.00062

Hobfoll, S.E. (2002). Social and psychological resources and adaptation. Review of General Psychology, 6, 307-324.

Hobfoll, S.E., \& Shirom, A. (2000). Conservation of resources theory: Applications to stress and management in the workplace. In R.T. Golembiewski (Ed.), Handbook of organizational behavior (2nd edn., pp. 57-81). New York: Dekker.

Ibarra, H. (2002). Working Identity. Cambridge, MA: Harvard Business School Press. PMCid:PMC1279305

Jackson, L.T.B. (2004). Burnout and work engagement of teachers in the North West Province. Unpublished doctoral thesis, North-West University, Potchefstroom, South Africa.

Koyuncu, M., Burke, R.J., \& Fiksenbaum, L. (2006). Work engagement among women managers and professionals in a Turkish bank. Potential antecedents and consequences. Equal Opportunities International, 25(4), 299-310. http://dx.doi. org/10.1108/02610150610706276 
Lee, M.D., \& Wagenmakers, E.J. (2005). Bayesian statistical inference in Psychology: Comment on Trafimow (2003). Psychological Review, 112(3), 662-668. http:// dx.doi.org/10.1037/0033-295X.112.3.668, http://dx.doi.org/10.1037/0033-295X. dx.doi.org/10.1037/0033-295x.

Loehr, J., \& Schwartz, T.T. (2003). The power of full engagement. New York: Free Press.

Luthans, F. (2002a). Positive organizational behavior: Developing and managing psychological strengths. Academy of Management Executive, 16(1), 57-72. http://dx.doi.org/10.5465/AME.2002.6640181

Luthans, F. (2002b). The need for and meaning of positive organizational behavior Journal of Organizational Behavior, 23, 695-706. http://dx.doi.org/10.1002/ job.165

Luthans, F. (2012). Psychological capital: Implications for HRD, retrospective analysis, and future directions. Human Resource Development Quarterly, 23(1), 1-8. http://dx.doi.org/10.1002/hrdq.21119

Luthans, F., Avey, J.B., \& Patera, J.L. (2008). Experimental analysis of a webbased training intervention to develop psychological capital. Academy of Management Learning and Education, 7, 208-221. http://dx.doi.org/10.5465/ Management Learning
AMLE.2008.32712618

Luthans, F., Avey, J.B., Avolio, B.J., Norman, S.M., \& Combs, G.J. (2006). Psychological capital development: Toward a micro-intervention. Journal of Organizational capital development: Toward a micro-intervention. Jou
Behavior, 27, 387-393. http://dx.doi.org/10.1002/job.373

Luthans, F., Avey, J.B., Avolio, B.J., \& Peterson, S.J. (2010). The development and resulting performance impact of psychological capital. Human Resource Development Quarterly, 21(1), 41-67. http://dx.doi.org/10.1002/hrdq.20034

Luthans, F., Avolio, B.J., Avey, J.B., \& Norman, S.M. (2007). Positive psychological capital: Measurement and relationship with performance and satisfaction. Personnel Psychology, 60, 541-572. http://dx.doi.org/10.1111/j.1744 6570.2007.00083.x

Luthans, F., Luthans, K.W., \& Luthans, B.C. (2004). Positive psychological capital: Beyond human and social capital. Business Horizons, 47(1), 45-50. http://dx.doi. org/10.1016/j.bushor.2003.11.007

Luthans, F., Norman, S.M., Avolio, B.J., \& Avey, J.B. (2008). The mediating role of psychological capital in the supportive organizational climate-employee performance relationship. Journal of Organizational Behavior, 29, 219-238. http://dx.doi.org/10.1002/job.507

Luthans, F., \& Youssef, C.M. (2004). Human, social, and now positive psychological capital management: Investing in people for competitive advantage. Organizational Dynamics, 33(2), 143-160. http://dx.doi.org/10.1016/j. orgdyn.2004.01.003

Luthans, F., \& Youssef, C.M. (2007). Emerging positive organizational behavior. Journa of Management, 33(3), 321-349. http://dx.doi.org/10.1177/0149206307300814

Luthans, F., Youssef, C.M., \& Avolio, B.J. (2007). Psychological capital. New York: Oxford University Press.

Macey, W.H., \& Schneider, B. (2008), The meaning of employee engagement. Industrial and Organizational Psychology, 1, 3-30. http://dx.doi.org/10.1111/ j.1754-9434.2007.0002.x

Maslach, C., Schaufeli, W.B., \& Leiter, M.P. (2001). Job burnout. Annual Review of Psychology, 52, 397-422. http://dx.doi.org/10.1146/annurev.psych.52.1.397, PMid:11148311

Minervini, R., Meyer, M., \& Rourke, L. (2003). Human capital management: A handbook for SA Managers. Johannesburg: WriteStuff Publishing. PMCid:PMC194939

Muthén, L.K., \& Muthén, B.O. (2013). Mplus: Statistical analysis with latent variables. User's guide (Version 7.11). Muthén and Muthén. PMCid:PMC3135722

Peterson, S.J., Luthans, F., Avolio, B.J., Walumba, F.O., \& Zheng, Z. (2011) Psychological capital and employee performance: A latent growth modelling
approach. Personnel Psychology, 64, 427-450. http://dx.doi.org/10.1111/j.1744approach. Personnel
6570.2011.01215.x

Rothmann, S. (2003). Job satisfaction, occupational stress, burnout and work engagement as components of work-related wellbeing. South African Journal of Industrial Psychology, 34(3), 11-16.

Rothmann, S., \& Joubert, J.H.M. (2007). Job demands, job resources, burnout and work engagement of managers at a platinum mine in the North-West Province. South African Journal for Business Management, 38(3), 49-61.

Salanova, M., Agut, S., \& Peiro, J.M. (2005). Linking organizational resources and work engagement to employee performance and customer loyalty: The mediation of service climate. Journal of Applied Psychology, 96, 1217-1227. http://dx.doi. org/10.1037/0021-9010.90.6.1217, PMid:16316275

Schabracq, M.J., \& Cooper, C.L. (2000). The changing nature of work and stress. Journal of Management Psychology, 15, 227-241. http://dx.doi. org/10.1108/02683940010320589
Schaufeli, W.B., \& Bakker, A.B. (2003). Utrecht Work Engagement Scale: Preliminary manual. Version 1. Utrecht: Occupational Health Psychology Unit, Utrecht University. PMCid:PMC1765719

Schaufeli, W.B. \& Bakker, A.B. (2013). Burnout en bevlogenheid [Burnout and work engagement]. In W.B. Schaufeli \& A.B. Bakker (Ed.), De psychologie van arbeid en gezondheid [The psychology of work and health] (pp. 305-322). Houten: en gezondheid [The psychology of work and health] (pp. 305-322). Houten:
Bohn Stafleu van Loghum. http://dx.doi.org/10.1007/978-90-313-9854-6 17, Bohn Stafleu van Loghum. http://dx.doi.org/1
http://dx.doi.org/10.1007/978-90-313-9854-6

Schaufeli, W.B., Bakker, A.B., \& Salanova, M. (2006). The measurement of Work Engagement with a short questionnaire: A Cross-National Study. Education and Psychological Measurement, 66(4), 701-716. http://dx.doi. Education and Psychological M
org/10.1177/0013164405282471

Schaufeli, W.B., Salanova, M., González-Romá, V., \& Bakker, A.B. (2002). The measurement of engagement and burnout: A two-sample confirmatory factor measurement of engagement and burnout: A two-sample confirmatory factor analytic approach. Journal of
org/10.1023/A:1015630930326

Seligman, M.E.P., \& Csikszentmihalyi, M. (2000). Positive psychology: An introduction. American Psychologist, 55(1), 5-14. http://dx.doi.org/10.1037/0003-066X.55.1.5, PMid:11392865

Simbula, S., Guglielmi, D., \& Schaufeli, W.B. (2011). A three-wave study of job resources, self-efficacy and work engagement among Italian school teachers. resources, self-efficacy and work engagement among Italian school teachers. European Journal of Work and Organizationa
dx.doi.org/10.1080/13594320903513916

Sonnentag, S. (2003). Recovery, work engagement, and proactive behaviour: A new look at the interface between non-work and work. Journal of Applied Psychology, 88, 518-528. http://dx.doi.org/10.1037/0021-9010.88.3.518, PMid:12814299

Stajkovic, A., \& Luthans, F. (1998). Self-efficacy and work-related performance: A metaanalysis. Psychological Bulletin, 124, 240-261. http://dx.doi.org/10.1037/00332909.124.2.240

Steyn, H.S. (1999). Praktiese betekenisvolheid: Die gebruik van effekgroottes. [Practical significance: The use of effect size.] Wetenskaplike bydraes-Reeks B: [Practical significance: The use of effect size.] Wetenskaplike bydraes-Reeks B:
Natuurwetenskappe Nr. 117. Potchefstroom: Potchefstroomse Universiteit vir Natuurwetenskappe Nr. 117.
Christelike Hoër Onderwys.

Storm, K., \& Rothmann, S. (2003). A psychometric analysis of the Utrecht Work Engagement Scale in the South African Police Service. South African Journal of Industrial Psychology, 29(4), 62-70.

Sweetman, D., \& Luthans, F. (2010). The power of positive psychology: Psychological capital and work engagement. In Bakker, A.B., \& Leiter, M.P. (Eds.), Work engagement: A handbook of essential theory and research (pp. 54-68). New York: engagement: $A$ hand
Psychology Press.

Van de Schoot, R., Hoijtink, H., \& Jan-Willem, R. (2011). Moving beyond tradiotiona null hypothesis testing: Evaluating expectations directly. Frontiers in Psychology, 2, 1-5. http://dx.doi.org/10.3389/fpsyg.2011.00024, PMid:21713172

Van de Schoot, R., \& Strohmeier, D. (2011). Testing informative hypotheses in SEM increases power: An illustration contrasting classical hypothesis testing with a parametric bootstrap approach. International Journal of Behavioral Development, 35(2), 180-190. http://dx.doi.org/10.1177/0165025410397432

Vrieze, S.I. (2012). Model selection and psychological theory: A discussion of the differences between the Akaike Information Criterion (AIC) and the Bayesian Information Criterion (BIC). Psychological Methods, 17(2), 228-243. http://dx.doi. org/10.1037/a0027127

Wagenmakers, E.J., Wetzels, R., Borsboom, D., \& Van der Maas, H. (2011). Why psychologists must change the way they analyze their data: The case of psi: Comment on Bem (2011). Journal of Personality and Social Psychology, 100, 426432. http://dx.doi.org/10.1037/a0022790, PMid:21280965

Xanthopoulou, D., Bakker, A.B., Demerouti, E., Schaufeli, W.B. (2007). The role of personal resources in the job demands-resources model. International Journal of Stress Management, 14, 121-141. http://dx.doi.org/10.1037/1072 5245.14.2.121

Xanthopoulou, D., Bakker, A.B., Demerouti, E., \& Schaufeli, W.B. (2009). Reciprocal relationships between job resources, personal resources, and work engagement. Journal of Vocational Behavior, 74, 235-244. http://dx.doi.org/10.1016/j. jvb.2008.11.003

Xanthopoulou, D., Bakker, A.B., Kantas, A., \& Demerouti, E. (2012). Measuring burnout and work engagement: Factor structure, invariance, and latent mean differences across Greece and the Netherlands. International Journal of Business Science and Applied Management, 7(2), 40-52

Youssef, C.M., \& Luthans, F. (2007). Positive organisational behaviour in the workplace. The impact of hope, optimism and resilience. Journal of Management, 33(5), 774-800. http://dx.doi.org/10.1177/0149206307305562 